\title{
An application of window data envelopment analysis methodology with double frontier in the performance assessment of Shiraz university colleges
}

\author{
Sahar Sharifian $^{\mathrm{a}^{*}}$, Abolghasem Ebrahimi $^{\mathrm{b}}$ and Moslem Alimohammadlou ${ }^{\mathrm{c}}$
}



\begin{abstract}
Nowadays efficiency measurement is considered as one of the most important methods for performance assessment of the organizations. Assessment of academic education and research system is a vital factor for education and research promotion and also is a panoramic mirror for education and research activities. The aim of this research is to assess the efficiency measurement of Shiraz university colleges over the period 2009 - 2014. Data Envelopment Analysis (DEA) as one of the most important methods of efficiency measurement has two limitations: First, it calculates cross-sectional efficiency values and second, it may consider many units as an efficient unit. Window Data Envelopment Analysis (WDEA) is used for eliminating the first limitation and similarly double frontier analysis is used to overcome the second limitation. The results show that proposed WDEA method with double frontier in comparison with traditional analysis, provides more accurate results.
\end{abstract}

(C) 2017 Growing Science Ltd. All rights reserved.

\section{Introduction}

Universities and their other subsystems are organizations with specific purposes and it is necessary to use appropriate tools for measuring their performances (Alam Tabriz, et al., 2010). Nowadays performance assessment of universities plays an important role for those how assign budget to these units (Balabonienè \& Večerskienè, 2014). Organizational performance assessment is a process through which we can evaluate an organization according to its objectives, mission and its success in achieving them. Performance evaluation is necessary for all organizations and provides them the opportunity to identify problems and take corrective actions. Every education system needs an educational and research evaluation when faces with changes (Kiakojoori, et al., 2011). Performance evaluation has

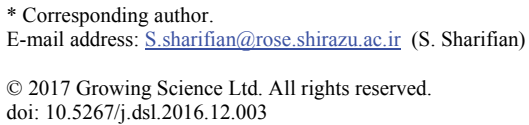


provided essential information for decision making and has gained competitive advantage for continuous operations in an organization (Hsieh \& Lin, 2010).

Man has always been confronted with the problem of resource limitation and scarce of facilities in all centuries. Even in advanced industrial countries, due to the increasing rate of population growth and scarcity of resources, efficient use of available resources is an excellent way to improve the welfare of human society. In fact, human efforts have always been focused on achieving maximum results with minimum resources (Emami Mibodi, 2006).

Managers have used several criteria such as effectiveness, efficiency, quality, productivity, profitability, and soon to evaluate the performance of their organizations (Mohammadi, et al., 2012). Performance measurement is one of the most important responsibilities of the managers that not only shows past achievements but also indicates future direction of development (Kao, 2016). Assessment of efficiency and productivity in service sector is not as simple as a manufacturing or commercial organizations especially at universities and higher education institutions, because the nature of services is different from products and cannot be stored (Heydari Nejad \& Mozafari, 2006). Data envelopment analysis (DEA) is one of the most practical methods for performance measurement. DEA is a methodology based on linear programming and is used to assess the relative efficiency of decision making units that perform the same tasks (Charles \& Zegarra, 2014).

In other words DEA is an effective technique for measuring the relative efficiency of decision making units, all of them use the same inputs produce the same outputs. Performance evaluation of these units is an important task for decision makers to recognize the weaknesses suggesting strategies to improve them as much as possible (Zhao, et al., 2011).

One of the weaknesses of the DEA is that it only deals whit cross sectional analysis and it does not review the efficiency over time, so, window data envelopment analysis is used to overcome this shortcoming. Window data envelopment analysis was raised by Charnes et al. (1985) where every single decision making unit is not compared with all data collections, but instead compared only with an alternative subset of panel data (Cullinane, et al., 2004).

In data envelopment analysis if the amounts of decision making unite were less than the number of input and output variables, some problems may arise in connection with lower degree of freedom. One way to overcome these problems is window data envelopment analysis (Kutlar, et al., 2015). Another shortcoming of DEA is that, its accuracy is low and only considers at the issue from one perspective (only optimistic). Intended purpose of optimistic is that efficient unit has the shortest distance to the efficient border. The concept of DEA makes it impossible to accurately measure the overall efficiency and DEA with double frontier has been proposed to address these shortcomings.

This method considers two efficiencies for decision making: The first measures the efficiency frontier and is called the best efficiency or optimistic efficiency, and the second measures deficiency frontier (or entry frontier) and is called the worst efficiency or pessimistic efficiency. Traditional data envelopment analysis just measures the best group relative efficiency of decision making units while avoiding pessimistic efficiency so it cannot provide an overall assessment of DMUs. Knowing the subjective preferences of decision makers and no need to civet calculations by simultaneous consideration of relative optimistic and pessimistic efficiency, all the DMUs can be fully rated (Wang \& Chin, 2009).

According to the rankings announced by various international institutions, Shiraz University in comparison with well-known national and international universities stands in low ranks. It seems that one of the main reasons for the low ranking of Shiraz University is the poor efficiency of its colleges which has caused the situation that expected outputs are not acquired from the limited resources. The 
aim of this study is the efficiency measurement of Shiraz university colleges and for the first time window data envelopment analysis with double frontier is employed. In the first stage of this study, previous studies and articles in the field of university efficiency evaluation with data envelopment analysis, and window data envelopment analysis with double frontier, were reviewed. Then, the research was conducted by background, inputs and output investigations and finally by calculating efficiency, the results were obtained and ranked.

\section{Literature Review}

Empowerment and success of any country in the global economy depends on the success of the organizations and their success depends on creativity, innovation and performance. Humans have always sought to achieve maximum results with minimum facilities, these efforts can be called as higher efficiency. Efficiency means less time or energy for most of the work which is done. In fact, efficiency is the ratio of work which is done to the amount of the work that needs to be done (Amani \& Arabzadeh, 2014). Efficiency is the ratio of goods production or final services to the resource which is used in their production (Sherman \& Ladino, 1995).

Efficiency means doing the right thing, achieving the expected level of output from a given input, producing less waste and spending the least amount of resources and effort while the quality and quantity are maintained (Mohammadi, et al., 2015). DEA has a long history in the evaluation of universities. Sinoni and Estern used data envelopment analysis to determine the efficiency of 21 Bangurian university colleges in 1994. In their survey, operation costs and university wages were considered as input and scholarships, the number of publications, the number of graduate students, the number of hours of courses were offered as output, the result of this study showed that 14 out of 21 colleges were inefficient.

Førsund and Ove Kalhagen (1999) in their study examined the efficiency and productivity of economic colleges of Norwegian universities using DEA and Malmquist index. The results showed that there was a big efficiency difference between professional and public universities. Also efficiency frontier moved higher, due to positive productivity growth of the most universities. In a study conducted out by Avkiran (2001) on 36 Australian universities in 1999, three sets of outputs included educational, financial and general, were assessed individually. Reducing efficiency rating in some units and stability rating in other units were seen, due to the reduced number of outputs on the implementation of the triple models and the root causes were addressed. Inputs included the faculty members of and non-academic staff while outputs included undergraduate registration, postgraduate registration and quantum researches.

Thursby and Kemp (2004), by using data from 112 universities and after implementation of DEA model, reviewed the correlation between increasing in inputs, increasing in rate of efficiency and extracting the roots of inefficiency using statistical methods. Inputs included: the number of patents, royalties, licenses and initiatives. Outputs included: the number of working professionals, the federal government support, the number of faculty members in colleges of biological sciences, engineering and physical sciences, and the quality of biological sciences, engineering and physical sciences.

Abbott and Doucouliagos (2003) used DEA method for measuring the efficiency of Australian universities. They considered research and education indices and social services as outputs while the number of faculty members, the number of non - academic staff, cost of university and the value of non - current assets were considered as input. Johnes (2008) reviewed the efficiency and productivity of UK higher education sector during 1996 to 2003. He surveyed the changes in productivity of 113 higher education institutions in England using Malmquist index. The results showed that on average, $1.5 \%$ of annual productivity growth the whole universities was the result of positive growth of technology, while technological efficiency had fallen $8 \%$ and it showed the importance of technological 
changes. His model included four inputs: students, full time faculty members, construction costs and MA students, and three outputs: graduates, postgraduates and revenue from research and education.

In a study, García-Aracil andPalomares-Montero (2008) reviewed technology and productivity changes using DEA and Malmquist index and the efficiency and performance of 43 public universities in Spain. Inputs were total fees, academic and non-academic staff and enrolled students. Outputs were graduates, publications and researches. The research period was 1994 to 2004 . The result showed that the average total annual productivity has increased by $4.6 \%$ that $0.06 \%$ was due to technical efficiency and $0.4 \%$ was due to technological efficiency. Net efficiency and scale efficiency respectively grew by $0.5 \%$ and $1 \%$. In general universities efficiency and productivity have improved.

Katharaki and Katharaki (2010) reviewed comparative evaluation of 20 Greek universities. Input indicators were the number of undergraduates and post graduates, the number of educational and research staffs, the number of enrolled students and operating costs. Output were the number of graduates and research incomes. Kiakojoori et al. (2011) evaluated the performance of 12 branches of Islamic Azad University of Mazandaran using data envelopment analysis. Input variables were educational resources (the number of students and faculty members) and service resources (administrative personnel, training site of each student and student's books). Output variables were educational (graduates) and research (research productivity, the number of internal, national and international seminars, the number of journals and publications of national and international papers). Noor branch had the highest efficiency and Chaloos had the lowest and the rest were placed between these two values.

Abd El-Razik (2015) reviewed the efficiency evaluation of 19 universities in Saudi Arabia using DEA method. Inputs included: budgets, the number of university teaching staff, the number of non - teaching staff and the number of colleges. Research outputs were considered: total number of enrolled students, total number of new students and the number of graduates. The results showed that only $53 \%$ of universities in the sample enjoyed a high level of efficiency while $48 \%$ of them were under efficiency frontier.

Gökşen et al. (2015) checked out the application of DEA for efficiency measurement of 26 colleges of universities in Turkey using input -based method. Inputs were the area within and outside the academy, the number of academic staff, the number of administrative staff .outputs were the number of publications and the number of graduates. As it was shown, efficiency measurement of universities by using data envelopment analysis has a long history. Although many researches were done in the field of window analysis (Wang \& Chin, 2009; Wang \& Zhang, 2013; Yang \& Chang, 2009), and in the field of data envelopment analysis with double frontier (Wang, et al., 2009, 2007; Wang \& Lan, 2013), the combination of these two methods are not generally been used in university evaluation. So the aim of this paper is to present combined method of data envelopment analysis with double frontier in university evaluation.

\section{Research method}

This study is an applied research and in terms of data collection is a descriptive case study. Statistical population of this research includes all 14 colleges of Shiraz University. However, because the information of newly established Theology and New technologies colleges was not available, these two colleges were excluded and 12 colleges were evaluated. In this study, the information of statistical yearbook of Shiraz University was used. Decision making units of this study were colleges of Shiraz University.

Collected data can be divided into two parts: inputs and outputs. To determine these inputs and outputs, background and related studies were investigated that can be seen in Table 1. 
Table 1

Indicators input and output based on literature review



Data envelopment analysis is a liner programing technic for relative measurement of efficiency which is composed of a decision making collection and is used to calculate the relative efficiency of organizations such as bank branches and universities (Thanassoulis et al., 2012). DEA is a method for evaluating organizations performance in private and public sectors (Sueyoshi \& Goto, 2011). It is a convenient and efficient tool which is used as a non - parametric method to calculate the efficiency of decision making units (Liu, et al., 2013). Most of the models which are used in data envelopment analysis are CCR and BCC, respectively constant and variable efficiency to the scale. With respect to model purpose, DEA can be divided into two types: input - based and output -based models. Input based models minimum inputs according to outputs, while output - based models maximum the outputs (Seol, et al., 2011). To formulate, consider N DMUs $(n=1,2, \ldots, N)$ that are observed in $\mathrm{T}$ period $(t=1,2, \ldots, T)$, and they were all input $r$ for producing $s$ output. So the sample has $\mathrm{T}^{*} \mathrm{~N}$ observations and an $n$ observation in $t$ period, $D M U_{t}^{n}$ has an input vector $X_{t}^{n}=\left(x_{1 t}^{n}, x_{2 t}^{n}, \ldots, x_{r t}^{n}\right)$ and an output vector $Y_{r}^{n}=\left(y_{1 r}^{n}, y_{2 r}^{n}, \ldots, y_{s t}^{n}\right)$. The window starts in $k \cdot 1 \leq k \leq T$ time and $w \cdot 1 \leq w \leq T-k$ wide and is shown by $K_{w}$ and have $N^{*} w$ observation.

Input matrixes of envelopment analysis are as follows: (Fallahi and Ahmadi, 2005)

$X_{k w}=\left(x_{k}^{1}, x_{k}^{2}, \ldots, x_{k}^{N}, x_{k+1}^{1}, x_{k+1}^{2}, \ldots x_{k+w}^{1}, x_{k+w}^{2}, \ldots x_{k+w}^{N}\right)$

Output matrixes:

$Y_{k w}=\left(y_{k}^{1}, y_{k}^{2}, \ldots, y_{k}^{N}, y_{k+1}^{1}, y_{k+1}^{2}, \ldots y_{k+w}^{1}, y_{k+w}^{2}, \ldots y_{k+w}^{N}\right)$

Input - based window data envelopment analysis problem for $D M U_{t}^{n}$ is given under an assumption of constant efficiency to scale:

$\operatorname{Min} \theta=\theta_{k w t}^{\prime}$

$\theta, \lambda$

subject to

$-X_{k w} \lambda+\theta X_{t}^{\prime} \geq 0$

$Y_{k w} \lambda-Y_{t}^{\prime} \geq 0$

$\lambda_{n} \geq 0 \quad\left(n=1, \ldots, k, \ldots, N^{*} W\right)$ 
By entering a multiplicative restriction for the model, the linear programming problem will be as:

$$
\begin{aligned}
& \operatorname{Min} \theta=\theta_{k w t}^{\prime} \\
& \theta, \lambda, z \\
& \text { subject to } \\
& -X_{k w} \lambda+\theta X_{t}^{\prime}+C_{z}^{i} \geq 0 \\
& Y_{k w} \lambda-Y_{t}^{\prime}+C_{z}^{0} \geq 0 \\
& \lambda_{n} \geq 0 \quad\left(n=1, \ldots, K, N^{*} W\right) \\
& Z \geq 0
\end{aligned}
$$

\section{Data Envelope Analysis with Double Frontier}

Data envelope analysis with double frontier considers two efficiencies for decision making. One of them is measured according to efficiency frontier and is called the best efficiency or optimistic efficiency. The other one is measured according to deficiency frontier or input frontier and is called the worst efficiency or pessimistic efficiency. Traditional data envelopment analysis just measures the best relative efficiency of decision making units by avoiding pessimistic efficiencies. So, it cannot present a comprehensive assessment of DMUs. With simultaneous consideration of optimistic and pessimistic efficiencies, all DMUs can be ranked without requiring a lot of computing and with knowing the subjective preferences of the decision makers. Suppose that a decision making unit should be evaluated according to input $m$ and outputs. Input values are shown by $x_{\mathrm{ij}},(\mathrm{i}=1,2, \ldots, \mathrm{m})$ symbol and output values are shown by $y_{\mathrm{rj}}$ '( $(\mathrm{r}=1,2, \ldots, \mathrm{s})$. A decision making unit efficiency is defined as follows that $U_{\mathrm{r}}$ and $V_{\mathrm{i}}$ are the weights which have respectively been determined for output $s$ and input $m$.

$\theta_{j}=\frac{\sum_{r=1}^{S} U_{r} Y_{r j}}{\sum_{i=1}^{m} V_{i} X_{i j}}$

\subsection{Optimistic data envelopment analysis}

In the first step, optimistic data envelopment analysis is conducted and decision making units are ranked in terms of optimistic efficiency. In optimistic approach if $\theta_{0}=1$, then under evaluation decision making unit is called as efficient, otherwise it is called as inefficient. In data envelopment analysis articles, optimistic efficiency is defined as CCR efficiency. For $n$ different decision making units, linear programming models will be solved $n$ times, each time for one decision making unit. All efficient decision making units constitute an efficient frontier, and they can be grouped for more analysis.

$\min \theta_{0}$

subject to

$\sum_{j=1}^{n} \lambda_{j} X_{i j} \leq \theta X_{i 0}, \quad i=1,2, \ldots, m$

$\sum_{j=1}^{n} \lambda_{j} Y_{r j} \geq Y_{r 0} \quad r=1,2, \ldots, s$

$\lambda_{j} \geq 0, \quad j=1,2, \ldots, n$

\subsection{Pessimistic data envelopment analysis}

In the second step, pessimistic data envelopment analysis is conducted and decision making units are ranked in terms of pessimistic efficiency. If $\varphi_{0}=1$, then the decision making unit which is under evaluation is called as pessimistic deficiency, otherwise it is called as pessimistic deficient decision making unit. This linear programming model will be solved $n$ times, each time for one decision making unit. All deficient decision making units constitute a deficient frontier, and they can be grouped for 
more analysis. Efficiency assessment results of all the colleges of shiraz university according to pessimistic analysis is illustrated in Table 3 .

$\operatorname{Max} \varphi_{\mathrm{o}}$

subject to

$\sum_{j=1}^{n} \lambda_{j} X_{i j} \geq \theta X_{i o}, \quad i=1,2, \ldots, m$

$\sum_{j=1}^{n} \lambda_{j} Y_{r j} \leq Y_{\text {ro }}, \quad r=1,2, \ldots, s$

$\lambda_{j} \geq 0, \quad j=1,2, \ldots, n$

\subsection{Window data envelopment analysis with double frontier}

Optimistic and pessimistic efficiencies can be measured from different perspectives which lead to two various rankings for colleges. So an overall performance is needed to achieve total rankings of colleges that are obtained with the below formula (Wang \& Chin, 2009).

$L\left(\varphi_{j}, \theta_{j}\right)=\left\{\begin{array}{cc}\frac{\varphi j-\theta j}{\ln \varphi j-\ln \theta j}, \quad \varphi *_{j}=\theta_{j} \\ \varphi_{j}, \quad \varphi_{j}=\theta_{j} & j=1,2, \ldots, n\end{array}\right.$

\section{Research findings}

Efficiency of 12 colleges were analyzed using data envelopment analysis software, and were calculated by excel software. Three windows can be assumed that each window covers 3 years. Efficiency values were always in $(0,1)$ interval. Efficiency assessment results of shiraz university`s colleges according to optimistic analysis are shown in Table 2 . In this table, rows represent windows and columns represent the years which have been studied.

As it is illustrated in Table 2, college of Economics, Management and Social Sciences, college of Science and college of Mechanical Engineering for the whole years are at full performance compared to other colleges. The average efficiency of these colleges are $100 \%$ so, with respect to other efficiencies have the highest ratings.

In terms of efficiency, Materials and Civil Engineering college, college of Arts and Architecture and college of Law and Political Science have the lowest ratings. Most of the units were defined as efficient and it demonstrates the weakness of optimistic analysis for differentiating faculties.

In optimistic analysis, most of the colleges stood first in rankings so to fix this flaw, pessimistic analysis was used. As it is shown in Table 3, college of Veterinary Medicine enjoys the highest efficiency (1.2575) and has stood in the first place.

In terms of efficiency, college of Agriculture was in the second place, college of Science was in the third place, college of Literature and Humanities was in the fourth place, college of Arts was in the fifth place, college of Mechanical Engineering was in the sixth place, college of Electrical and Computer Engineering was in the seventh place, Chemical Engineering and college of Oil and Gas were in the eighth place, college of Education and Psychology was in the ninth place and college of Economics, Management and Social Science, college of Law and Political Science, college of Materials and Civil Engineering were in last place. By benchmarking of efficient colleges they colleges can achieve ideal level of efficiency. 
Table 2

Average optimistic analysis for each college

\begin{tabular}{|c|c|c|c|c|c|c|c|}
\hline Colleges & Window & $\begin{array}{c}200 \\
9\end{array}$ & $\begin{array}{c}201 \\
0\end{array}$ & $\begin{array}{c}201 \\
1\end{array}$ & $\begin{array}{c}201 \\
2\end{array}$ & $\begin{array}{c}201 \\
3\end{array}$ & $\begin{array}{c}\text { Averag } \\
\mathrm{e}\end{array}$ \\
\hline \multirow{4}{*}{ College of Literature and Humanities } & W1 & 1 & 0.62 & 0.88 & & & 0.83 \\
\hline & W2 & & 0.60 & 0.85 & 1 & & 0.82 \\
\hline & W3 & & & 0.83 & 0.99 & 1 & 0.94 \\
\hline & Average & 1 & 0.62 & 0.86 & 0.99 & 1 & $\mathbf{0 . 8 7}$ \\
\hline \multirow{4}{*}{$\begin{array}{c}\text { College of Economics, Management and } \\
\text { Social Science }\end{array}$} & W1 & 1 & 1 & 1 & & & 1 \\
\hline & W2 & & 1 & 1 & 1 & & 1 \\
\hline & W3 & & & 1 & 1 & 1 & 1 \\
\hline & Average & 1 & 1 & 1 & 1 & 1 & 1 \\
\hline \multirow{4}{*}{ College of Law and Political Science } & W1 & 0.64 & 0.64 & 0.70 & & & 0.67 \\
\hline & W2 & & 1 & 1 & 1 & & 1 \\
\hline & W3 & & & 1 & 1 & 1 & 1 \\
\hline & Average & 0.64 & 0.82 & 0.90 & 1 & 1 & 0.89 \\
\hline \multirow{4}{*}{ College of Veterinary Medicine } & W1 & 1 & 0.77 & 0.79 & & & 0.86 \\
\hline & W2 & & 0.87 & 0.94 & 1 & & 0.94 \\
\hline & W3 & & & 0.93 & 0.93 & 0.89 & 0.92 \\
\hline & Average & 1 & 0.82 & 0.89 & 0.96 & 0.89 & 0.90 \\
\hline \multirow{4}{*}{ College of Science } & $\mathrm{W} 1$ & 1 & 1 & 1 & & & 1 \\
\hline & W2 & & 1 & 1 & 1 & & 1 \\
\hline & W3 & & & 1 & 1 & 1 & 1 \\
\hline & Average & 1 & 1 & 1 & 1 & 1 & 1 \\
\hline \multirow{4}{*}{ College of Education and Psychology } & $\mathrm{W} 1$ & 1 & 0.79 & 1 & & & 0.93 \\
\hline & W2 & & 0.87 & 1 & 1 & & 0.96 \\
\hline & W3 & & & 1 & 1 & 1 & 1 \\
\hline & Average & 1 & 0.83 & 1 & 1 & 1 & 0.96 \\
\hline \multirow{4}{*}{ College of Agriculture } & $\mathrm{W} 1$ & 1 & 1 & 1 & & & 1 \\
\hline & W2 & & 1 & 1 & 1 & & 1 \\
\hline & W3 & & & 1 & 1 & 1 & 1 \\
\hline & Average & 1 & 1 & 1 & 1 & 1 & 1 \\
\hline \multirow{4}{*}{$\begin{array}{c}\text { College of Electrical and Computer } \\
\text { Engineering }\end{array}$} & W1 & 1 & 1 & 1 & & & 1 \\
\hline & W2 & & 0.89 & 1 & 1 & & 0.96 \\
\hline & W3 & & & 1 & 1 & 1 & 1 \\
\hline & Average & 1 & 0.95 & 1 & 1 & 1 & 0.98 \\
\hline \multirow{4}{*}{ College of Chemical Engineering, Oil and Gas } & W1 & 1 & 1 & 1 & & & 1 \\
\hline & W2 & & 1 & 1 & 1 & & 1 \\
\hline & W3 & & & 1 & 1 & 1 & 1 \\
\hline & Average & 1 & 1 & 1 & 1 & 1 & 1 \\
\hline \multirow{4}{*}{ College of Mechanical Engineering } & W1 & 1 & 1 & 1 & & & 1 \\
\hline & W2 & & 1 & 1 & 1 & & 1 \\
\hline & W3 & & & 1 & 1 & 1 & 1 \\
\hline & Average & 1 & 1 & 1 & 1 & 1 & 1 \\
\hline \multirow{4}{*}{ College of Materials and Civil Engineering } & W1 & 1 & 0.70 & 0.89 & & & 0.86 \\
\hline & W2 & & 0.58 & 0.78 & 0.62 & & 0.66 \\
\hline & W3 & & & 0.79 & 0.59 & 1 & 0.79 \\
\hline & Average & 1 & 0.64 & 0.82 & 0.61 & 1 & 0.77 \\
\hline \multirow{4}{*}{ College of Arts and Architecture } & $\mathrm{W} 1$ & 0.96 & 0.86 & 0.89 & & & 0.91 \\
\hline & W2 & & 0.75 & 0.66 & 1 & & 0.80 \\
\hline & W3 & & & 0.66 & 1 & 1 & 0.89 \\
\hline & Average & 0.96 & 0.81 & 0.74 & 1 & 1 & 0.87 \\
\hline
\end{tabular}


Table 3

Average Pessimistic analysis for separating the colleges

\begin{tabular}{|c|c|c|c|c|c|c|c|}
\hline faculties & Window & 2009 & 2010 & 2011 & 2012 & 2013 & Average \\
\hline \multirow{4}{*}{ College of Literature and Humanities } & W1 & 1.24 & 1 & 1.17 & & & 1.14 \\
\hline & W2 & & 1 & 1.21 & 1 & & 1.07 \\
\hline & W3 & & & 1 & 1 & 1 & 1 \\
\hline & Average & 1.24 & 1 & 1.12 & 1 & 1 & 1.07 \\
\hline \multirow{4}{*}{$\begin{array}{c}\text { College of Economics, Management and } \\
\text { Social Science }\end{array}$} & W1 & 1 & 1 & 1 & & & 1.00 \\
\hline & W2 & & 1 & 1 & 1 & & 1 \\
\hline & W3 & & & 1 & 1 & 1 & 1 \\
\hline & Average & 1 & 1 & 1 & 1 & 1 & 1.00 \\
\hline \multirow{4}{*}{ College of Law and Political Science } & W1 & 1 & 1 & 1 & & & 1.00 \\
\hline & W2 & & 1 & 1 & 1 & & 1 \\
\hline & W3 & & & 1 & 1 & 1 & 1 \\
\hline & Average & 1 & 1 & 1 & 1 & 1 & 1.00 \\
\hline \multirow{4}{*}{ College of Veterinary Medicine } & W1 & 2.06 & 1.24 & 1.4 & & & 1.57 \\
\hline & W2 & & 1.08 & 1.20 & 1.32 & & 1.20 \\
\hline & W3 & & & 1 & 1.00 & 1 & 1.00 \\
\hline & Average & 2.06 & 1.16 & 1.20 & 1.16 & 1 & 1.26 \\
\hline \multirow{4}{*}{ College of Science } & W1 & 1.3 & 1.15 & 1.16 & & & 1.21 \\
\hline & W2 & & 1.23 & 1.19 & 1 & & 1.14 \\
\hline & W3 & & & 1.17 & 1 & 1 & 1.06 \\
\hline & Average & 1.31 & 1.19 & 1.18 & 1 & 1 & 1.14 \\
\hline \multirow{4}{*}{ College of Education and Psychology } & W1 & 1 & 1 & 1.01 & & & 1.00 \\
\hline & W2 & & 1 & 1 & 1 & & 1 \\
\hline & W3 & & & 1 & 1 & 1 & 1 \\
\hline & Average & 1 & 1 & 1.00 & 1 & 1 & 1.01 \\
\hline \multirow{4}{*}{ College of Agriculture } & W1 & 1.65 & 1.24 & 1.29 & & & 1.39 \\
\hline & W2 & & 1 & 1 & 1.02 & & 1.07 \\
\hline & W3 & & & 1 & 1.04 & 1 & 1.01 \\
\hline & Average & 1.65 & 1.11 & 1.09 & 1.03 & 1 & 1.13 \\
\hline \multirow{4}{*}{$\begin{array}{c}\text { College of Electrical and Computer } \\
\text { Engineering }\end{array}$} & W1 & 1 & 1.01 & 1 & & & 1.00 \\
\hline & W2 & & 1.01 & 1 & 1 & & 1.00 \\
\hline & W3 & & & 1 & 1 & 1.14 & 1.04 \\
\hline & Average & 1 & 1.01 & 1 & 1 & 1.14 & 1.01 \\
\hline \multirow{4}{*}{ College of Chemical Engineering, Oil and gas } & W1 & 1 & 1 & 1.07 & & & 1.02 \\
\hline & W2 & & 1 & 1.00 & 1 & & 1.00 \\
\hline & W3 & & & 1 & 1 & 1 & 1 \\
\hline & Average & 1 & 1 & 1.02 & 1 & 1 & 1.00 \\
\hline \multirow{4}{*}{ College of mechanical engineering } & W1 & 1 & 1 & 1.05 & & & 1.01 \\
\hline & W2 & & 1 & 1 & 1.02 & & 1.00 \\
\hline & W3 & & & 1 & 1.11 & 1 & 1.03 \\
\hline & Average & 1 & 1 & 1.01 & 1.07 & 1 & 1.02 \\
\hline \multirow{4}{*}{ College of Materials and Civil Engineering } & W1 & 1 & 1 & 1 & & & 1.00 \\
\hline & W2 & & 1 & 1 & 1 & & 1 \\
\hline & W3 & & & 1 & 1 & 1 & 1 \\
\hline & Average & 1 & 1 & 1 & 1 & 1 & 1.0000 \\
\hline \multirow{4}{*}{ College of Arts and Architecture } & W1 & 1.30 & 1 & 1 & & & 1.10 \\
\hline & W2 & & 1 & 1 & 1.02 & & 1.00 \\
\hline & W3 & & & 1 & 1.03 & 1 & 1.01 \\
\hline & Average & 1.30 & 1 & 1 & 1.02 & 1 & 1.03 \\
\hline
\end{tabular}

Window data analysis results with double frontier are obtained by using total performance formula which is shown in table 4. 
Table 4

Window data analysis results with double frontier

\begin{tabular}{|c|c|c|c|c|c|c|c|}
\hline College & Window & 2009 & 2010 & 2011 & 2012 & 2013 & Average \\
\hline \multirow{4}{*}{ College of Literature and Humanities } & W1 & 1.12 & 0.79 & 1.02 & & & \multirow[b]{4}{*}{0.97} \\
\hline & W2 & & 0.78 & 1.02 & 1.00 & & \\
\hline & W3 & & & 0.91 & 0.99 & 1.00 & \\
\hline & Average & 1.11 & 0.79 & 0.98 & 0.99 & 1.00 & \\
\hline \multirow{4}{*}{ College of Economics, Management and Social Science } & W1 & 1.000 & 1.000 & 1.000 & & & \multirow[b]{4}{*}{1.00} \\
\hline & W2 & & 1.00 & 1.00 & 1.00 & & \\
\hline & W3 & & & 1.00 & 1.00 & 1.00 & \\
\hline & Average & 1.00 & 1.00 & 1.00 & 1.00 & 1.00 & \\
\hline \multirow{4}{*}{ College of Law and Political Science } & W1 & 0.80 & 0.81 & 0.84 & & & \multirow[b]{4}{*}{0.93} \\
\hline & W2 & & 1.00 & 1.00 & 1.00 & & \\
\hline & & & & 1.00 & 1.00 & 1.00 & \\
\hline & Average & 0.80 & 0.90 & 0.95 & 1.00 & 1.00 & \\
\hline \multirow{4}{*}{ College of Veterinary Medicine } & W1 & 1.47 & 0.99 & 1.07 & & & \multirow[b]{4}{*}{1.09} \\
\hline & W2 & & 0.97 & 1.07 & 1.16 & & \\
\hline & W3 & & & 0.96 & 0.97 & 0.95 & \\
\hline & Average & 1.47 & 0.98 & 1.03 & 1.06 & 0.95 & \\
\hline \multirow{4}{*}{ College of Science } & W1 & 1.15 & 1.07 & 1.08 & & & \multirow[b]{4}{*}{1.06} \\
\hline & W2 & & 1.11 & 1.09 & 1.00 & & \\
\hline & W3 & & & 1.08 & 1.00 & 1.00 & \\
\hline & Average & 1.15 & 1.09 & 1.08 & 1.00 & 1.00 & \\
\hline \multirow{4}{*}{ College of Education and Psychology } & W1 & 1.00 & 0.89 & 1.00 & & & \multirow[b]{4}{*}{0.98} \\
\hline & W2 & & 0.93 & 1.00 & 1.00 & & \\
\hline & W3 & & & 1.00 & 1.00 & 1.00 & \\
\hline & Average & 1.00 & 0.91 & 1.00 & 1.00 & 1.00 & \\
\hline \multirow{4}{*}{ College of Agriculture } & W1 & 1.30 & 1.12 & 1.14 & & & \multirow[b]{4}{*}{$1 / 08$} \\
\hline & W2 & & 1.00 & 1.00 & 1.01 & & \\
\hline & W3 & & & 1.00 & 1.02 & 1 & \\
\hline & Average & 1.30 & 1.06 & 1.05 & 1.02 & 1 & \\
\hline \multirow{4}{*}{ College of Electrical and Computer Engineering } & W1 & 1.00 & 1.00 & 1.00 & & & \multirow[b]{4}{*}{1.00} \\
\hline & W2 & & 0.95 & 1.00 & 1.00 & & \\
\hline & W3 & & & 1.00 & 1.00 & 1.07 & \\
\hline & Average & 1.00 & 0.98 & 1.00 & 1.00 & 1.07 & \\
\hline \multirow{4}{*}{ College of Chemical Engineering, Oil and Gas } & W1 & 1.00 & 1.00 & 1.03 & & & \multirow[b]{4}{*}{1.03} \\
\hline & W2 & & 1.00 & 1.00 & 1.00 & & \\
\hline & W3 & & & 1.00 & 1.00 & 1.00 & \\
\hline & Average & 1.00 & 1.00 & 1.01 & 1.00 & 1.00 & \\
\hline \multirow{4}{*}{ College of Mechanical Engineering } & W1 & 1.00 & 1.00 & 1.02 & & & \multirow[b]{4}{*}{1.09} \\
\hline & W2 & & 1.00 & 1.00 & 1.01 & & \\
\hline & W3 & & & 1.00 & 1.06 & 1.00 & \\
\hline & Average & 1.00 & 1.00 & 1.00 & 1.03 & 1.00 & \\
\hline \multirow{4}{*}{ College of Materials and Civil Engineering } & W1 & 1.00 & 0.84 & 0.95 & & & \\
\hline & W2 & & 0.77 & 0.88 & 0.79 & & \\
\hline & W3 & & & 0.89 & 0.77 & 1.00 & \\
\hline & Average & 1.00 & 0.80 & 0.90 & 0.78 & 1.00 & 0.90 \\
\hline & W1 & 1.12 & 0.93 & 0.94 & & & \\
\hline Colleoe of Arts and Architecture & W2 & & 0.87 & 0.82 & 1.01 & & \\
\hline College or Arts and Arcnitecture & W3 & & & 0.82 & 1.01 & 1.00 & \\
\hline & Average & 1.12 & 0.90 & 0.86 & 1.01 & 1.00 & 0.98 \\
\hline
\end{tabular}

The average efficiency of all colleges for each year are illustrated in Table 4. For example, average efficiency of college of Literature and humanities from 2010 to 2014, were respectively 1.118, 0.793, $0.985,0.995$ and 1 . Overall average of efficiency for this faculty was 0.978 So, this college stands in the $10^{\text {th }}$ place among 12 colleges. By combining optimistic and pessimistic results and by using total performance formula, more exact results were presented, and a different ranking was executed. According to Table 5 college of Veterinary Medicine, college of Agriculture and college of Science respectively stood in the first to the third place. 
Another finding of this study is optimal values in outputs that can be declared for each unit as deficient. Optimal values of each colleges with respect to all analysis are shown in Table 5. Target values for each colleges have been extracted from pessimistic and optimistic analysis for different years by DIP and LINGO Softwares. Then minimum amount for inputs and maximum amount for outputs were calculated. In the next step, available values for inputs and outputs are extracted and finally target values were subtracted from available values and variable values obtained. Negative sign in "change" row showed that the index should decrease to achieve its own target value.

For example, college of Literature and Humanities with available value of 454 graduates, must bring the number of graduates to 650 and also should compensate the other shortcoming in input and output values to reach the efficient frontier. Other colleges can get the efficient frontier in the same way.

Table 5

Optimal values of each faculties

\begin{tabular}{|c|c|c|c|c|c|c|c|c|c|c|}
\hline College & & $\begin{array}{l}\text { number of } \\
\text { graduates }\end{array}$ & $\begin{array}{l}\text { Promotion } \\
\text { of } \\
\text { professors }\end{array}$ & $\begin{array}{l}\text { Efficien } \\
\text { cy } \\
\text { Points }\end{array}$ & $\begin{array}{l}\text { The volume } \\
\text { of contracts }\end{array}$ & $\begin{array}{l}\text { number of } \\
\text { professors }\end{array}$ & $\begin{array}{l}\text { number of } \\
\text { students }\end{array}$ & $\begin{array}{l}\text { Special } \\
\text { Price }\end{array}$ & $\begin{array}{l}\text { Number of } \\
\text { Employees }\end{array}$ & $\begin{array}{l}\text { Area } \\
\text { faculty }\end{array}$ \\
\hline \multirow{3}{*}{$\begin{array}{l}\text { College of Literature } \\
\text { and Humanities }\end{array}$} & available & 454 & 4.65 & 60 & 0 & 82.15 & 609 & 82231064 & 12 & 30566 \\
\hline & change & 195.68 & 18.55 & 1.29 & 4530114446 & -21.934 & -139.55 & -62810946 & 0 & 0 \\
\hline & Optimal & 649.68 & 23.20 & 61.29 & 4530114446 & 60.216 & 469.44 & 19420118 & 12 & 30566 \\
\hline \multirow{3}{*}{$\begin{array}{l}\text { College of } \\
\text { Economics, } \\
\text { Management and } \\
\text { Social Science }\end{array}$} & available & 261 & 5.8 & 39 & 3060079128 & 64.8 & 529 & 28414481 & 11 & 5650 \\
\hline & change & 161 & 0 & 4 & 0 & -42.15 & -101 & -12545916 & 0 & 0 \\
\hline & Optimal & 422 & 5.8 & 43 & 3060079128 & 22.65 & 428 & 15868565 & 11 & 5650 \\
\hline \multirow{3}{*}{$\begin{array}{l}\text { College of Law and } \\
\text { Political Science }\end{array}$} & available & 184 & 2.7 & 28 & 0 & 33.55 & 358 & 24456452 & 9 & 7700 \\
\hline & change & 92.62 & 1.86 & 7.74 & 3100907376 & -6.75 & -93 & -16340869 & 0 & 0 \\
\hline & Optimal & 276.62 & 4.56 & 35.74 & 3100907376 & 26.8 & 265 & 8115583 & 9 & 7700 \\
\hline \multirow{3}{*}{$\begin{array}{c}\text { College of } \\
\text { Veterinary Medicine }\end{array}$} & available & 686.4 & 6.7 & 56 & 35000000 & 84.65 & 924 & 73743134 & 24 & 34837 \\
\hline & change & 481.43 & 5.26 & 17.82 & 5004898311 & -5.35 & -121.22 & -40087713 & -2.204 & 0 \\
\hline & Optimal & 1167.83 & 11.96 & 73.82 & 5039898311 & 79.3 & 802.77 & 33655421 & 21.796 & 34837 \\
\hline \multirow{3}{*}{ College of Science } & available & 771.12 & 11.35 & 120 & 13885667323 & 173.1 & 1898.4 & 138912705 & 44 & 39117 \\
\hline & change & 589.68 & 7.01 & 1 & 84601220.92 & -19.35 & -139.44 & -79618325 & 0 & 0 \\
\hline & Optimal & 1360.8 & 18.36 & 121 & 13970268544 & 153.75 & 1758.96 & 59294380 & 44 & 39117 \\
\hline \multirow{3}{*}{$\begin{array}{l}\text { College of Education } \\
\text { and Psychology }\end{array}$} & available & 499 & 9.3 & 50 & 2065220000 & 69.35 & 634 & 41989740 & 11 & 8500 \\
\hline & change & 52 & 0 & 8 & 0 & -16.54 & -213.20 & -24311681 & 0 & 0 \\
\hline & Optimal & 551 & 9.3 & 58 & 2065220000 & 52.80 & 420.79 & 17678059 & 11 & 8500 \\
\hline \multirow{3}{*}{$\begin{array}{l}\text { College of } \\
\text { Agriculture }\end{array}$} & available & 2569.6 & 13.65 & 86 & 1226000000 & 146.45 & 2153.8 & 117185008 & 43 & 33198 \\
\hline & change & 773.50 & 9.23 & 9 & 2508650506 & -12.5 & 0 & -74240503 & 0 & 0 \\
\hline & Optimal & 3343.10 & 22.88 & 95 & 3734650506 & 133.95 & 2153.8 & 42944505 & 43 & 33198 \\
\hline \multirow{3}{*}{$\begin{array}{l}\text { College of Electrical } \\
\text { and Computer } \\
\text { Engineering }\end{array}$} & available & 521.7 & 8.7 & 52 & 27128029200 & 72.85 & 1333.85 & 33974329 & 17 & 17544 \\
\hline & change & 33.991 & 4.08 & 0 & 9232358920 & -16.45 & -221.31 & -17080659 & -21.95215 & 0 \\
\hline & Optimal & 555.69 & 12.78 & 52 & 36360388120 & 56.4 & 1112.53 & 16893670 & -4.95215 & 17544 \\
\hline College of Chemical & available & 334.85 & 0.0001 & 22 & 32955710000 & 32.65 & 671.55 & 15331223 & 7 & 22000 \\
\hline \multirow{2}{*}{$\begin{array}{c}\text { Engineering, Oil and } \\
\text { Gas }\end{array}$} & change & 251.6 & 4.34 & 0 & 0 & -11.3 & -105.45 & -8852236 & 0 & 0 \\
\hline & Optimal & 586.45 & 4.35 & 22 & 32955710000 & 21.35 & 566.1 & 6478987 & 7 & 22000 \\
\hline \multirow{3}{*}{$\begin{array}{l}\text { College of } \\
\text { Mechanical } \\
\text { Engineering }\end{array}$} & available & 403.3 & 1.45 & 33 & 3859979887 & 47.15 & 899.1 & 2859223 & 8 & 7800 \\
\hline & change & 313.73 & 7.85 & 5.127625 & 3459521269 & -8.05 & -164.13 & -850209 & 0 & 0 \\
\hline & Optimal & 717.03 & 9.3 & 38.127625 & 7319501156 & 39.1 & 734.96 & 2009014 & 8 & 7800 \\
\hline \multirow{3}{*}{$\begin{array}{c}\text { College of } \\
\text { Materials and } \\
\text { Civil Engineering }\end{array}$} & available & 379.25 & 1.75 & 33 & 44741591558 & 48.35 & 801.05 & 79590756 & 22 & 13661 \\
\hline & change & 1615.05 & 2.73 & 12.754 & 0 & -19.95 & -102.47 & -65467303 & -6.424 & 0 \\
\hline & Optimal & 1994.3 & 4.48 & 45.754 & 44741591558 & 28.4 & 698.57 & 14123453 & 15.576 & 13661 \\
\hline \multirow{3}{*}{$\begin{array}{l}\text { College of Arts and } \\
\text { Architecture }\end{array}$} & available & 384 & 0 & 26 & 1591000000 & 8.75 & 687 & 27471259 & 15 & 9000 \\
\hline & change & 1778.65 & 3.85 & 11.703 & 2846022667 & 0 & -192.41 & -20220829 & 0 & 0 \\
\hline & Optimal & 2162.65 & 3.85 & 37.703 & 4437022667 & 8.75 & 494.58 & 7250430 & 15 & 9000 \\
\hline
\end{tabular}

\section{Conclusion}

Data envelopment analysis (DEA) as one of most important ways for measuring efficiency has two limitations as follows. First, it calculates the value of efficiency in a cross-sectional way and secondly, it may consider most of units as an efficient unit. To overcome first limitation window analysis and for the second one double frontier analysis have been used. In window analysis, data were edited and calculated by using DIP software in way of 3 windows and colleges of Economics, Management, Social Sciences, Agriculture, Chemistry, Oil and Gas are in the most efficient colleges. In this analysis, as efficiency of most of colleges was 1, Pessimistic analysis was used. Pessimistic analysis happened by writing 108 models in LINGO software, and based on the results colleges of veterinary, Agriculture and Science earned ranking of 1 to 3. 
Finally the result showed colleges of Veterinary, Agriculture, Electrical and Computer Engineering, Mechanical Engineering, Science, Chemistry Engineering and Oil and Gas and Economy, Management and Social Science as efficient units, and colleges of Literature and Humanities, Education and Psychology Science, Art and Architecture, Law and Political Science, Materials Engineering and Civil in category of inefficient colleges. The results of survey have indicated that the proposed method of data envelopment analysis of window data with double frontier provides more accurate results compared to traditional analysis.

According to the research findings and inputs and outputs of the research, the following suggestions will be presented: All the 12 colleges can set time limit for duration of Education to increase their graduated students. All colleges except Economics, Management and Social Sciences and Educational Science and Psychology can review the regulation of promotion of their faculty members in a way that their promotion be dependent to increase of outputs inorder to provide motivations for promoted professors and facilitate the administrative. All the colleges, except Electrical and Computer Engineering and Chemistry Engineering, Oil and Gas can promote their efficiency rate in research and educational activities, by formally announcing and appreciating these faculty members whit the highest performance. All the colleges except college of Economics, Management, and Social Science, Educational Science and Psychology, Chemistry Engineering, Oil and Gas, and Civil Engineering should increase the amount of their contract value so that their efficiency improves. By using distinguished professors they can increase the interaction between the university and industry. Also the exclusive expenses of all colleges should decrease, so that it improves their efficiency. They can get the significant improvement in total productivity by implementing cost project in each colleges and designing performance budgeting system and also executing related projects. Colleges like Veterinary, Electrical and Computer Engineering and Material and Civil Engineering can improve their efficiency by outsourcing some of their activities for reducing their staff. It is suggested that future researchers use Meta frontier analysis, combination of window data envelopment analysis double frontier with Malmquist double frontier analysis and it can provide good results for identifying the displacement of efficient border and calculation of different kinds of efficiencies and use other variables that was not covered this research.

\section{References}

Abbott, M., \& Doucouliagos, C. (2003). The efficiency of Australian universities: a data envelopment analysis. Economics of Education review, 22(1), 89-97.

García-Aracil, A., \& Palomares-Montero, D. (2008, September). Evaluation of Spanish universities: Efficiency, technology and productivity change. In Prime-Latin America Conference at Mexico City, September.

Ahn, T., \& Seiford, L. M. (1993). Sensitivity of DEA to models and variable sets in a hypothesis test setting: The efficiency of university operations. Creative and innovative approaches to the science of management, 191-208.

Alam Tabriz, A., Deylami Moezi, S., \& Saiedy, H.(2010). Using an integrated approach DEA and AHP to evaluate the Efficiency Evaluation Faculties of University, Journal of Management Studies, 89, 25-36. [Persian].

Alam Tabriz, A., Faraji, R., \& Saiedy, H. (2010). Efficiency Evaluation Faculties of Shahid Beheshti University using Composed Approach of DEA and Goal Programming Model. Industrial Management Studies, 8(19), 1-22. [Persian].

Amani, B., \& Arabzadeh, S. M. (2014). Performance evaluation of data service units, window coverings case study analysis approach SAIPA Isfahan province, Industrial Engineering Research Conference. [Persian].

Afonso, A., \& Santos, M. (2008). A DEA approach to the relative efficiency of Portuguese public universities. Portuguese Journal of Management Studies, 13(1), 67-87. 
Avkiran, N. K. (2001). Investigating technical and scale efficiencies of Australian universities through data envelopment analysis. Socio-Economic Planning Sciences, 35(1), 57-80.

Balabonienè, I., \& Večerskienè, G. (2014). The peculiarities of performance measurement in universities. Procedia-Social and Behavioral Sciences, 156, 605-611.

Bessent, A. M., Bessent, E. W., Charnes, A., Cooper, W. W., \& Thorogood, N. C. (1983). Evaluation of educational program proposals by means of DEA. Educational Administration Quarterly, 19(2), 82-107.

Charles, V., \& Zegarra, L. F. (2014). Measuring regional competitiveness through data envelopment analysis: A peruvian case. Expert Systems with Applications, 41(11), 5371-5381.

Cullinane, K., Song, D. W., Ji, P., \& Wang, T. F. (2004). An application of DEA windows analysis to container port production efficiency. Review of network Economics, 3(2).

Emami Meibodi, A. (2006). Efficiency and productivity measurement (in theory and practice). [Persian]

Fallahi, M.A., \& Ahmadi, V. (2005). Cost Efficiency Analysis of Electricity Distribution Companies in Iran, Journal of Economic Researches, 71, 297-320.

Førsund, F. R., \& Kalhagen, K. O. (1999). Efficiency and productivity of Norwegian Colleges. In Data Envelopment Analysis in the Service Sector (pp. 269-308). Deutscher Universitätsverlag.

Flegg, A. T., Allen, D. O., Field, K., \& Thurlow, T. W. (2003). Measuring the efficiency and productivity of British universities: an application of DEA and the Malmquist approach. University of the West of England, Department of Economics, series Discussion Papers, 304.

Gökşen, Y., Doğan, O., \& Özkarabacak, B. (2015). A Data Envelopment Analysis Application for Measuring Efficiency of University Departments. Procedia Economics and Finance, 19, 226-237.

Heydari Nejad, S., \& Mozafari, AA. (2006). Evaluation of efficiency phisical educations faculties and departments by DEA Olympic J, Vol. 14(2), 7-17. [Persian].

Hsieh, L. F., \& Lin, L. H. (2010). A performance evaluation model for international tourist hotels in Taiwan-An application of the relational network DEA. International Journal of Hospitality Management, 29(1), 14-24.

Johnes, J. (2008). Efficiency and productivity change in the English higher education sector from 1996/97 to 2004/5. The Manchester School, 76(6), 653-674.

Kao, C. (2016). Efficiency decomposition and aggregation in network data envelopment analysis. European Journal of Operational Research.

Katharaki, M., \& Katharakis, G. (2010). A comparative assessment of Greek universities' efficiency using quantitative analysis. International journal of educational research, 49(4), 115-128.

Kiakojoori, D., Aghajani, H., Roudgarnezhad, F., Alipour, H., \& Kojoori, K. K. (2011). Performance Appraisal of Islamic Azad University Branches of Mazandaran Provinceusing data envelopment analysis. Australian Journal of Basic and Applied Sciences, 5, 840-848.

Kutlar, A., Kabasakal, A., \& Babacan, A. (2015). Dynamic Efficiency of Turkish Banks: a DEA Window and Malmquist Index Analysis for the Period of 2003-2012. Sosyoekonomi, 23(24).

Liu, J. S., Lu, L. Y., Lu, W. M., \& Lin, B. J. (2013). A survey of DEA applications. Omega, 41(5), 893-902.

Martín, E. (2006). Efficiency and Quality in the Current Higher Education Context in Europe: an application of the data envelopment analysis methodology to performance assessment of departments within the University of Zaragoza. Quality in higher education, 12(1), 57-79.

Mohammadi, A., Mohammadi, K., \& Jahanbani, M. (2012) Improve Measurement Efficiency in Data Envelopment Analysis, Using Data Envelopment Analysis Gray, Iran Management Research, 17, $152-135$.

Mousakhani, M., Vadoodimofid, B., \& Hamidi, N.(2005). Developing a model for efficiency and productivity growth in higher education centers. Quarterly Science Journal of Management, 3(6), 45-53. [Persian].

El-Razik, E. A. (2015). Data Envelopment Analysis a Technique for Measuring Efficiency. British Journal of Mathematics \& Computer Science, 5(6), 763. 
Safdari Ranjbar, M., Khalili, M., Azami, A., \& Sabzekar, A. (2010). Evaluate the performance of universities and colleges from the perspective of knowledge production using data envelopment analysis (Case study: Amirkabir University), Journal of Operation Research in its Aplication, 2(37), 61-76. [Persian].

Sameti, M., \& Rezvani, M. A. (2002). Efficiencyof Majnr Universities in Iran (using DEA Method), Journal of Economic Research, 59(2), 117-147. [Persian].

Seol, H., Lee, S., \& Kim, C. (2011). Identifying new business areas using patent information: A DEA and text mining approach. Expert Systems with Applications, 38(4), 2933-2941.

Sharei, Z. (2010). Evaluate and compare performance using DEA in PNU South Khorasan province, according to the Centers Grant Scheme PNU, third National Conference DEA, Islamic Azad University of Boroujerd. [Persian].

Sherman, H. D., \& Ladino, G. (1995). Managing bank productivity using data envelopment analysis (DEA). Interfaces, 25(2), 60-73.

Shoja, N., Falah Jelodar, M., \& Darvish Motavali, M. H. (2010). Determine the efficiency of District 12 Islamic Azad University using multi-component model in DEA, Journal of Operation Research in its Aplication, 2(29), 11-28. [Persian].

Sidorenko, T., \& Gorbatova, T. (2015). Efficiency of Russian Education Through the Scale of World University Rankings. Procedia-Social and Behavioral Sciences, 166, 464-467.

Sinuany-Stern, Z., Mehrez, A., \& Barboy, A. (1994). Academic departments efficiency via DEA. Computers \& Operations Research, 21(5), 543-556.

Sueyoshi, T., \& Goto, M. (2011). A combined use of DEA (data envelopment analysis) with strong complementary slackness condition and DEA-DA (discriminant analysis). Applied Mathematics Letters, 24(7), 1051-1056.

Thanassoulis, E., Kortelainen, M., \& Allen, R. (2012). Improving envelopment in data envelopment analysis under variable returns to scale. European journal of operational research, 218(1), 175-185.

Thursby, J. G., \& Kemp, S. (2002). Growth and productive efficiency of university intellectual property licensing. Research policy, 31(1), 109-124.

Wang, K., Yu, S., \& Zhang, W. (2013). China's regional energy and environmental efficiency: A DEA window analysis based dynamic evaluation. Mathematical and Computer Modelling, 58(5), $1117-$ 1127.

Wang, Y. M., \& Chin, K. S. (2009). A new approach for the selection of advanced manufacturing technologies: DEA with double frontiers. International Journal of Production Research, 47(23), 6663-6679.

Wang, Y. M., \& Lan, Y. X. (2013). Estimating most productive scale size with double frontiers data envelopment analysis. Economic Modelling, 33, 182-186.

Yang, H. H., \& Chang, C. Y. (2009). Using DEA window analysis to measure efficiencies of Taiwan's integrated telecommunication firms. Telecommunications Policy, 33(1), 98-108.

Zhao, Y., Triantis, K., Murray-Tuite, P., \& Edara, P. (2011). Performance measurement of a transportation network with a downtown space reservation system: A network-DEA approach. Transportation Research Part E: Logistics and Transportation Review, 47(6), 11401159.

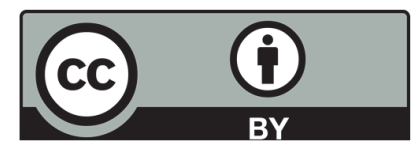

(C) 2017 by the authors; licensee Growing Science, Canada. This is an open access article distributed under the terms and conditions of the Creative Commons Attribution (CC-BY) license (http://creativecommons.org/licenses/by/4.0/). 